\title{
PENGARUH VARIASI LAMA FERMENTASI TERHADAP KANDUNGAN PROTEIN PADA TAPE TALAS (Colocasia esculenta) SEBAGAI SUMBER BELAJAR BIOLOGI SMA KELAS XII PADA MATERI BIOTEKNOLOGI PENGOLAHAN BAHAN PANGAN
}

\author{
Eka Baskara Prasetyajati \\ Agus Sujarwanta \\ Pendidikan Biologi FKIP Universitas Muhammadiyah Metro \\ E-mail: baswaelah@gmail.com
}

\begin{abstract}
The purpose of this study was 1 ) to determine whether or not the effect of fermentation time variation of the protein produced on tape taro. 2 ) to determine variations in fermentation hours to obtain the highest protein content of the tape taro. The study design used was completely randomized design with 4 treatments and 5 replications. Parameters measured were crude protein content and organoleptic tape taro. The results showed that the fermentation time affect the protein content of the resulting tape taro, the highest protein content in treatment $C$ (fermented 60 hours) resulted in as much as $3.888 \%$ protein. Based on the test results BNJ all treatments were significantly different with the exception of treatment $B$ and $D$. Benefits in the manufacture of tape taro research are: the lecturer can be used as teaching materials practicum taro tape processing methods on the biology subject matter in the form of LKPS biotechnology, and science can contribute to the reader about alternative ways of processing of taro as a traditional food.
\end{abstract}

Kata Kunci: lama fermentasi, kandungan protein tape talas.

Talas merupakan tanaman pangan alternatif Indonesia yang sudah lama dibudidayakan masyarakat Indonesia. Bukan hanya di negara Indonesia talas dibudidayakan, tetapi secara luas di kawasan Asia Pasifik, Amerika Tengah, dan Afrika. Kultur talas memiliki banyak ragam terutama di daerah-daerah yang merupakan sentra produksi talas seperti Bogor, Malang, Mentawai, Lampung, Sulawesi (Selatan dan Utara) dan Irian Jaya yaitu jenis Colocasia, Cyrtosperma, Alocasia, dan Xanthosoma, dari sekian banyak jenis talas yang telah diketahui, talas yang paling banyak dibudidayakan di seluruh kepualuan Indonesia adalah jenis Colocasia, yaitu Colocasia esculenta yang banyak dijumpai di Provinsi Lampung.

Provinsi Lampung merupakan salah satu sentra produksi talas di Indonesia, namun pengolahan umbi talas ini sendiri belum maksimal dalam konsumsi rumah tangga. Hal ini terbukti dari segi penjualan talas di pasar-pasar tradisional Lampung makanan olahan dari talas sangat jarang ditemui. Bahkan pengolahan talas di daerah sentra terbesar provinsi Lampung yaitu, di Lampung Barat pengolahanya pun belum maksimal (Ermayuli:2011).

Talas dari mulai daun dan umbinya mempunyai kandungan gizi yang cukup baik. Talas mengandung unsur mineral dan vitamin, sehingga dapat dijadikan obat-obatan, umbi talas juga berpotensi sebagai sumber karbohidrat dan protein yang cukup tinggi. Umbi talas juga mengandung lemak, vitamin A, B1 dan sedikit vitamin C (Richana:2012). Telah diketahui talas memiliki banyak sekali manfaat bagi manusia. Selain diolah sebagai sumber makanan pokok, talas juga bermanfaat sebagai camilan teman 
minum teh atau kopi, di goreng, di rebus, di buat keripik, dan diolah menjadi tepung. Di Indonesia sendiri talas lebih banyak diolah dengan cara di kukus, di kolak, di goreng, di buat kripik yang cukup lezat, ataupun di jadikan sebagai bahan tambahan sayuran bagi ibu rumah tangga untuk memasak, dari sekian banyak manfaat talas dan kandungan gizi yang dimilikinya, masih banyak masyarakat yang kurang dalam memanfaatkan talas ini khususnya masyarakat Kota Metro dan daerah-daerah lainya di propinsi Lampung, kebanyakan masyarakat dalam pemanfaatan talas hanya di olah dengan cara di goreng dan dikukus saja sebagai camilan. Untuk itu, perlu adanya manfaat peningkatan umbi talas guna meningkatkan pendapatan petani talas khusunya di Provinsi Lampung.

Hasil dari pembuatan tape talas ini dapat diaplikasikan di dunia pendidikan yaitu kegiatan praktikum yang bisa di lakukan oleh siswa dengan mudah tanpa perlu mengeluarkan banyak biaya seperti pengolahan keju, yogurt dan lain-lain yang prosesnya cukup sulit dan memakan waktu lebih lama, sehingga pembuatan tape inilah yang dapat dijadikan salah satu alternatif lain dalam kegiatan pembelajaran bagi siswa. Konsep pembelajaran biologi yang diajarkan pada siswa Sekolah Menengah Atas (SMA) khususnya pokok bahasan bioteknologi tertuang pada materi yang sudah ditetapkan yaitu "Membuat rencana dan melaksanakan pembuatan produk bioteknologi konvensional dan menyusun laporan secara rinci."

\section{METODE}

Penelitian menggunakan metode eksperimen dengan Rancangan Acak Lengkap (RAL) dengan 4 perlakuan dan 5 pengulangan, lama fermentasi yaitu 48 jam, 54 jam, 60 jam, dan 66 jam untuk masing-masing 100 gram talas.

Cara Kerja Pembuatan Tape Talas (diadaptasi dari Wulandari: 2012)

1. Memilih Talas yang baik sebanyak 2500gram kemudian mengupas kulitnya dan mencuci hingga bersih lalu memotongnya menjadi beberapa bagian kecil dengan ukuran $2 \times 2 \mathrm{~cm}$ bagian yang sama.

2. Merendam talas dengan air hangat \pm 3 jam.

3. Mengukus potongan talas selama 20 menit dalam dandang.

4. Mendinginkan talas hingga mencapai suhu kamar. Setelah talas menjadi dingin menaburkan ragi tape yang telah dihaluskan sebelumnya dengan jumlah takaran ragi yang sama yaitu 0,5 gram,untuk 100 gram talas kukus.

5. Membungkus potongan talas yang telah ditaburi ragi dalam daun pisang kemudian memfermentasikan talas selama 48, 54, 60 dan 66 jam dalam tempat tertutup .

6. Panen tape talas kemudian melihat kandungan proteinnya

Penentuan Kandungan Protein

(Metoda Gunning) dilakukan di

Laboraturium THP Polinela

1. Menimbang secara seksama 0,5 - 1 gram bahan yang telah dihaluskan dan memasukan kedalam labu Kjedahl, menambahkan 10 gr $\mathrm{K}_{2} \mathrm{~S}$ atau $\mathrm{Na}_{2} \mathrm{SO}_{4}$ anhidrat, dan $10-15$ $\mathrm{ml} \mathrm{H}_{2} \mathrm{SO}_{4}$. Kalau distruksi sukar perlu melakukan penambahan $0,1-$ 0,3 gram $\mathrm{CuSO}_{4}$ dan kocok-kocok.

2. Kemudian melakukan distruksi diatas pemanas listrik dalam lemari asam. Mula-mula dengan api kecil, setelah asap hilang api dibesarkan, pemanasan diakhiri setelah cairan menjadi jernih sedikit kebiruan. 
3. Membuat perlakukan blanko, yaitu perlakuan seperti diatas tanpa sampel.

4. Setelah dingin, menambahkan 100 ml Aquades kedalam labu Kjeldhal, serta menambahkan larutan $\mathrm{NaOH}$ $45 \%$ sampai cairan basis. Memasang labu Kjeldhal dengan segera pada alat distilasi.

5. Memasukan labu kjeldhal sampai amonia menguap semua, menampung distilat dalam elenmeyer berisi $25 \mathrm{ml} \mathrm{HCl} 0,1 \mathrm{~N}$ yang sudah diberi indikator fenolptalein $1 \%$ beberapa tetes. Mengakhiri distilasi setelah distilat tertampung sebanyak $150 \mathrm{ml}$ atau distilat yang keluar tidak berbasis.

6. Menitritasi dengan larutan $\mathrm{NaOH}$ 0,1 $\mathrm{N}$ hingga merah muda, Jika kelebihan $\mathrm{HCl} 0,1 \mathrm{~N}$ dalam distilat, kemudian mencatat jumlah $\mathrm{NaOh}$ yang digunakan.

7. $\%$ Protein $=\% \mathrm{~N} x$ Faktor Konversi Sumber: (dimodifikasi dari Merrill dan Watt dalam Kusnanto, 2012)

\section{Penilaian Uji Organoleptik}

Uji organoleptik adalah uji yang dilakukan dengan alat indra dengan menguji tingkat kesukaan, uji dilakukan dilingkungan sekitar kampus Universitas Muhammadiyah Metro. Penilaian ini meliputi warna, rasa, bau dan tekstur yang ditentukan dengan uji kesukaan panelis, (Dewi:2008).

\section{HASIL}

Berikut ini disajikan data hasil analisis kandungan protein tape talas berdasarkan pengaruh lama fermentasi.

Tabel 1. Data Hasil Analisis Protein Tape Talas

\begin{tabular}{|c|c|c|c|c|c|c|c|}
\hline \multirow[t]{2}{*}{ No } & \multirow{2}{*}{$\begin{array}{c}\text { Kode } \\
\text { Sampel }\end{array}$} & \multirow{2}{*}{$\begin{array}{c}\text { Sampel } \\
\text { (gr X 10) }\end{array}$} & \multicolumn{2}{|c|}{ Titrasi $(\mathrm{ml})$} & \multirow{2}{*}{$\begin{array}{c}\text { Protein } \\
(\%)\end{array}$} & \multirow{2}{*}{$\begin{array}{c}\text { Total } \\
(\%)\end{array}$} & \multirow{2}{*}{$\begin{array}{c}\text { Rata- } \\
\text { rata } \\
(\%)\end{array}$} \\
\hline & & & Blanko & Sampel & & & \\
\hline 1 & A. 1 & 16,118 & 32,3 & 26,7 & 3,0418 & \multirow[t]{5}{*}{15.664} & \multirow[t]{5}{*}{3.1328} \\
\hline 2 & A. 2 & 15,044 & 32,3 & 26,9 & 3,1426 & & \\
\hline 3 & A. 3 & 16,904 & 32,3 & 26,2 & 3,1593 & & \\
\hline 4 & A. 4 & 16,903 & 32,3 & 26,2 & 3,1595 & & \\
\hline 5 & A.5 & 16,896 & 32,3 & 26,2 & 3,1608 & & \\
\hline 6 & B. 1 & 15,599 & 32,3 & 26,5 & 3,2553 & \multirow[t]{5}{*}{16.387} & \multirow[t]{5}{*}{3.2771} \\
\hline 7 & B. 2 & 16,698 & 32,3 & 26,1 & 3,2507 & & \\
\hline 8 & B. 3 & 16,856 & 32,3 & 26,0 & 3,2722 & & \\
\hline 9 & B. 4 & 16,424 & 32,3 & 26,1 & 3,3050 & & \\
\hline 10 & B.5 & 16,171 & 32,3 & 26,2 & 3,3025 & & \\
\hline 11 & C. 1 & 19,559 & 32,3 & 24,8 & 3,3572 & \multirow[t]{5}{*}{16.941} & \multirow[t]{5}{*}{3.3888} \\
\hline 12 & C. 2 & 16,100 & 32,3 & 26,1 & 3,3715 & & \\
\hline 13 & C. 3 & 17,467 & 32,3 & 25,6 & 3,3582 & & \\
\hline 14 & C. 4 & 17,534 & 32,3 & 25,5 & 3,3953 & & \\
\hline 15 & C. 5 & 16,691 & 32,3 & 25,7 & 3,4619 & & \\
\hline 16 & D.1 & 15,710 & 32,3 & 26,5 & 3,2323 & \multirow[t]{5}{*}{16.245} & \multirow[t]{5}{*}{3.2495} \\
\hline 17 & D. 2 & 15,640 & 32,3 & 26,5 & 3,2467 & & \\
\hline 18 & D. 3 & 17,288 & 32,3 & 25,9 & 3,2411 & & \\
\hline 19 & D. 4 & 18,799 & 32,3 & 25,3 & 3,2600 & & \\
\hline 20 & D.5 & 17,149 & 32,3 & 25,9 & 3,2674 & & \\
\hline
\end{tabular}

Keterangan: 
A1, A2, A3, A4, A5 :Lama Fermentasi 48 Jam

B1, B2, B3, B4, B5 :Lama Fermentasi 54 Jam

C1, C2, C3, C4, C5 :Lama Fermentasi 60 Jam

D1, D2, D3, D4, D5 :Lama Fermentasi 66 Jam

\section{PEMBAHASAN}

\section{Kandungan Protein Tape Talas}

Talas mentah memiliki

kandungan protein $1,5 \%$, setelah talas diolah menjadi tape dan diberikan perlakuan dengan lama fermentasi tape terdapat perubahan kandungan protein. Protein yang terkandung dalam tape talas semakin lama fermentasi maka akan menurun kandungan protein didalamnya. Menurunya kandungan protein pada tape talas terjadi karena proses hidrolisis protein dalam talas semakin besar. Oleh karena itu, semakin lama proses fermentasi pada tape talas, maka semakin rendah pula kadar protein yang dimilikinya. Akan tetapi pada lama waktu fermentasi tertentu protein yang dimiliki tape talas meningkat. Hal ini terjadi karena dalam proses fermentasi mikroba akan menghasilkan enzim yang akan mendegradasi senyawa-senyawa kompleks menjadi sederhana dan mikroba juga akan mensintesis protein yang merupakan proses Protein enrichement yaitu pengkayaan bahan protein.

Dalam penelitian ini pada perlakuan fermentasi 60 jam yang memiliki kandungan protein tertinggi. Peningkatan kandungan protein ini terbukti dari hasil uji BNJ bahwa perlakuan lama fermentasi 60 jam yang menghasilkan kandungan protein tertinggi dibandingkan dengan perlakuan lain. Berbeda dengan perlakuan lama fermentasi 66 jam, kandungan protein yang dihasilkan tape talas semakin kecil. Penurunan kandungan protein yang dihasilkan tape talas ini tak lepas dari perkembangan dan pertumbuhan mikroba itu. Tahapan pertumbuhan mikroba dalam 4 fase, yaitu fase adaptasi (lag phase), fase pertumbuhan (expontial/logarithmic phase), fase stasioner (stationary phase), dan fase kematian (death phase). Fase pertama adalah adaptasi yang merupakan fase dimana pada saat ini posisi pertumbuhan mikroba cenderung lambat dan cenderung mikroba beradaptasi menyesuaikan lingkungan yang baru. Fase kedua adalah pertumbuhan yang merupakan fase dimana mikroba sudah mulai mampu beradaptasi terhadap lingkungan hidup yang baru, dan mikroba sudah mampu bekembang biak dalam lingkungan tersebut. Fase ketiga adalah fase stasioner yang merupakan dimana kematian dan pertumbuhan mikroba dalam lingkungan tersebut seimbang. Fase keempat adalah fase kematian yang merupakan fase akhir dari pertumbuhan mikroba, dalam fase ini jumlah kematian mikroba lebih besar daripada jumlah pertumbuhan mikroba.

Pada waktu lama fermentasi 48 sampai dengan 60 jam merupakan masa pertumbuhan mikroba, dan mencapai titik puncak pada waktu 60 jam, karena pada waktu 60 jam ini mikroba berada pada tahap logarithmic phase yang merupakan massa pertumbuhan mikroba yang akan meningkatkan kandungan protein. Kandungan protein yang dihasilkan merupakan refleksi dari jumlah massa sel. Mikroba akan mensintesis protein yang merupakan proses protein enrichment yaitu proses peningkatan protein. Sedangkan pada waktu fermentasi 66 jam mikroba mengalami death phase yang merupakan fase 
kematian, sehingga kandungan protein yang dimiliki tape talas mulai menurun, dan lebih kecil dari perlakuan 54 dan 60 jam. Didalam tape talas jenis mikrobanya adalah kapang Aspergilius yang mengubah karbohidrat menjadi glukosa dan khamir Saccharommyces, yang mengubah glukosa menjadi alkohol.

\section{Uji Organoleptik Tape Talas} a. Warna Tape Talas

Winarno (2004) menjelaskan

bahwa warna merupakan salah satu komponen atribut penting dalam organoleptik. Warna menjadi salah satu faktor yang menentukan mutu secara kasat mata atau secara visual. Berdasarkan data yang didapat hasil uji organoleptik warna pada tape talas menunjukan hampir semua panelis menyatakan warna dari tape talas adalah putih keabu-abuan. Untuk perlakuan pertama, kedua, ketiga dan keempat secara berurutan persentase dari 20 orang panelis yang menyatakan warna tape talas putih abu-abu ada $45 \%, 65 \%, 25 \%$, dan $40 \%$. Warna dominan putih abu-abu ini merupakan karakteristik dari talas bentul. Dapat disimpulkan untuk organoleptik warna putih abu-abu merupakan warna terbaik tape talas.

\section{b. Aroma Tape Talas}

Aroma terkait dengan indra pembau pada manusia. Rianne dalam Nababan (2012) memaparkan bahwa "siklus aroma dan keinginan untuk mengkonsumsi makanan, tidak terjadi pada saat kita mengunyah makanan. Hasil uji organoleptik aroma tape talas menunjukan bahwa dari semua perlakuan fermentasi adalah fermentasi 60 jam untuk menghasilkan aroma terbaik. Pada waktu ini terdapat $40 \%$, sedangkan pada fermentasi 48 dan 54 jam hanya mendapat $5 \%$, dan fermentasi 66 jam mendapat $0 \%$ dari
20 panelis yang menyatakan aroma tape talas sangat khas tape dan tajam. Santosa (2010) mejelaskan aroma tape merupakan hasil uap dari proses pengolahan makanan, uap ini tercipta dari bahan-bahan makanan yang diolah. Aroma khas tape yang berbau tajam ini berasal dari ragi yang bekerja dalam proses fermentasi yang merombak zat pati menjadi alkohol.

\section{c. Rasa Tape Talas}

Berdasarkan hasil uji organoleptik rasa tape talas di ketahui bahwa dari 4 perlakuan yang di ujikan dalam uji ini perlakuan fermentasi 60 jam yang paling di suka oleh panelis, yaitu berkisar $50 \%$ menyatakan sangat enak, sedangkan pada fermentasi 48 jam hanya $5 \%$, fermentasi 54 jam $25 \%$ dan fermentasi 66 jam 0\%. Tape yang melalui fermentasi anaerob akan memiliki rasa manis dibandingkan denan tape hasil fermentasi aerob, hal ini disebabkan karena mikroba yang terkandung dalam ragi ini tidak dapat melakukan kativitasnya dengan sempurna bila dengan fermentasi aerob (Khasanah :2012). Tape memiliki rasa manis keasaman, dan mengandung alkohol.

\section{d. Tekstur Tape Talas}

Tape umumnya mempunyai tekstur yang lunak, berair, bertekstur lengket dan lembut (Santosa:2010), hal ini disebabkan karena dalam proses fermentasi terjadi penguraian gula sederhana menjadi alkohol yang disertai dengan pelepasan kandungan air, sehingga air dalam bahan makanan semakin meningkat dan menyebabkan tekstur dari tape tersebut menjadi sangat lunak. Selain itu juga faktor pengukusan juga mempengaruhi tekstur dari tape talas. Semakin lama proses pengukusan maka tekstur tape talas akan lebih lunak, hal ini dikarenakan saat selama proses pengukusan dapat meningkatkan 
kandungan air pada talas. Berdasarkan uji organoleptik tekstur tape talas, semua panelis menyatakan tape talas memiliki tekstur yang lunak. Namun dari semua perlakuan yaitu perlakuan fermentasi 60 jam yang memiliki tekstur paling lunak menurut pendapat 20 panelis.

\section{e. Daya Terima Tape Talas}

Berdasarkan data hasil uji organoleptik daya terima tape talas, perlakuan yang menunjukkan persentase daya terima tertinggi yaitu pada perlakuan $\mathrm{C}$ (fermentasi 60 jam) terdapat $30 \%$ yang sangat menyukai tape talas, sedangkan persentase terendah yaitu pada perlakuan A dan D, dari kedua perlakuan tersebut tidak ada sama sekali orang yang sangat menyukai tape talas dan untuk perlakuan B hanya mendapat $5 \%$ yang sangat menyukai tape talas. Berdasarkan pernyataan panelis yang memilih fermentasi 60 jam sebagai kesukaanya karena pada fermentasi ini tape benar-benar telah layak dikonsumsi, dan memiliki warna putih keabu-abuan sebagai karakter tape talas, memiliki aroma yang sangat khas tape dan berbau tajam, rasanyapun sangat enak dengan tekstur yang lunak menjadikan perlakuan fermentasi 60 jam lebih diterima oleh panelis.

\section{Pemanfaatan Hasil Penelitian Sebagai Sumber Belajar}

Pembuatan tape talas diharapkan banyak memberikan manfaat bagi masyarakat umum, pendidik, pelajar sampai peneliti-peneliti lain. Dalam dunia pendidikan dan sains pembuatan tape tergolong dalam bioteknologi konvensional, karena dalam tahap pembuatanya melibatkan mikroba. Pembuatan tape diharapkan dapat dijadikan bahan ajar oleh guru dalam kegiatan praktikum bioteknologi pangan.
Sebagai seorang guru, khususnya guru biologi seorang guru harus dituntut mampu mengembangkan bahan ajar. Inilah salah satu alternatif pengembahan bahan ajar guru yang bisa diterapkan dalam kegiatan belajar siswa. Penerapan pembelajaran bagi siswa bisa dibuat dalam bentuk Lembar Kerja Praktikum Siswa (LKPS) berupa kegiatan praktikum siswa dalam pembuatan makanan contoh dari bioteknologi konvensional. Dimana siswa diminta membuat suatu produk makanan dengan memanfaatkan bahanbahan yang berada di sekitar tempat tinggal siswa.

Mengacu tujuan dari kurikulum 2013 yaitu menghasilkan manusia yang produktif, kreatif, inovatif, dan afektif serta mampu berkontribusi bagi kehidupan, bermasyarakat, berbangsa, bernegaram dan peradaban dunia serta memiliki kemampuan hidup sebagai pribadi dan warga negara yang beriman. Proses pembelajaran dengan kegiatan paraktikum pembuatan tape talas diharapkan bagi siswa mampu memahami konsep penerapan bioteknologi konvensional dalam kehidupan seharai-hari. Selain itu proses pembelajaran dengan sistem praktikum diharapkan mampu meningkatkan kreativitas siswa dan kemampuan siswa dalam materi bioteknologi konvensional khusunya dalam pengolahan bahan pangan, serta memberikan alternatif sumber belajar bagi siswa.

Semua proses yang dilakukan dalam penelitian ini terdapat keterampilan proses sains yang dapat diterapkan dalam pembelajaran bagi siswa, proses sains tersebut meliputi perumusan masalah, pengumpulan informasi, penentuan hipotesis, eksperimen, pengumpulan data, analisis data, dan penarikan kesimpulan. Proses sains yang 
dilakukan dalam penelitian ini dirasa dapat memudahkan guru dalam pembuatan konsep yang dapat dikembangkan menjadi kompetensi yang harus dicapai oleh peserta didik sehingga dapat dijadikan sebagai sumber belajar biologi.

\section{DAFTAR RUJUKAN}

Dewi, Sofya Khusuma. 2008. Pembuatan Produk Nasi Singkong Instan Berbasis Fermented Cassava Flour Sebagai Bahan Pangan Pokok Alternatif. Skripsi. Bogor: IPB.

Ermayuli. 2011. Skala Kecil pada Berbagai Proses Pembuatan Keripik Talas di Kabupaten Lampung Barat Lampung. (Online) Tesis tidak diterbitkan Universitas Lampung. (http://jurnal.fp.unila.ac.id. Diakses 4 November 2013)

Kusnanto, Febri. 2012. Pengaruh Waktu Fermentasi Terhadap Kadar Protein dan Daya Terima Tempe Biji Karet (Havea brasiliensis) sebagai Sumber Belajar Biologi SMA pada Materi Pokok Bioteknologi Pangan. Metro Universitas Muhammadiyah Metro.

Nababan, Erika, dkk. 2012. Uji Daya Terima Tempe Biji Kecipir Beras
Merah dan Kandungan Gizinya. Journal: Gizi, Kesehatan Reproduksi dan Epidemiologi. (Online) Vol I, No 01, 2012. (http://jurnal.usu.ac.id. Diakses 12 Maret 2013).

Richana, Nur. 2012. Manfaat UmbiUmbian

Indonesia.Bandung:Nuansa.

Santoso Agus dan Cucut Prakoso. 2010. Karakteristik Tape Buah Sukun Hasil Fermentasi Penggunaan Konsentrasi Ragi Yang Berbeda.(Online) Magistra No. 73 Th. XXII September 2010 ISSN 0215-9511. (http://journal.unwidha.ac.id. Diakses 4 Mei 2013).

Winarno, F.G. 2004. Kimia Pangan dan Gizi. Jakarta : Gramedia.

Wulandari, Badrisyiyani Eko. 2012. Penggunaan Modul Hasil Penelitian Identifikasi Fungi Dalam Tape Talas sebagai Sumber Belajar Biologi Dan Dampaknya terhadap Keterampilan Menginterprestasi Data Pada Siswa Kelas X SMA. (Online). Surakarta: Skripsi tidak diterbitkan FKIP Universitas Sebelas Maret Surakarta. (https://www.academia.edu .Diakses 2 April 2013) 